Pesq. Vet. Bras. 36(9):864-868, setembro 2016

DOI: $10.1590 / \mathrm{S} 0100-736 \mathrm{X000900012}$

\title{
Evidence of leptospiral exposure in neotropical primates rescued from illegal trade and a Zoo in Bahia, Brazil ${ }^{1}$
}

\author{
Daniela S. Almeida ${ }^{2,3}$, Andréia C. dos Santos ${ }^{3}$, Caroline Luane R. da Silva ${ }^{3,4}$, Arianne \\ P. Oriá ${ }^{2}$, Alberto Vinicius D. Oliveira ${ }^{5}$, Fernanda A. Libório ${ }^{6}$, Daniel A. Athanazio ${ }^{3,7 *}$ \\ and Melissa H. Pinna ${ }^{2}$
}

\begin{abstract}
Almeida D.S, Santos A.C., Silva C.L.R., Oriá A.P., Oliveira A.V.D., Libório F.A., Athanazio D.A. \& Pinna M.H. 2016. Evidence of leptospiral exposure in neotropical primates rescued from illegal trade and a Zoo in Bahia, Brazil. Pesquisa Veterinária Brasileira 36(9):864-868. Departamento de Patologia e Medicina Legal, Praça XV de Novembro s/n, Largo do Terreiro de Jesus, Salvador, BA 40025-010, Brazil. E-mail: daa@ufba.br

Few studies have compared the seroprevalence of antileptospiral agglutinins with the demonstration of urinary shedding of leptospires or evidence of active infection in the bloodstreams of non-human primates. The study population consists of 58 animals, including d 42 monkeys from the Zoological Park of Salvador (Parque Zoobotânico Getúlio Vargas), Bahia, Brazil. The study also evaluated 16 primates (Cebus sp.) rescued from illegal trade that were housed in the Wildlife Rehabilitation Center of Salvador (CETAS), Bahia, Brazil. The seroprevalence of antileptospiral antibodies was low (2\%) in the animals from the Zoo. A higher rate $(31 \%)$ was observed among the animals that were rescued from illegal trade in the state of Bahia. Even if all the blood and urine samples were negative for leptospiral DNA fragments, the high frequency of serological evidence of exposure suggests a potential risk of leptospirosis transmission when keeping these animals as pets.
\end{abstract}

INDEX TERMS: Leptospirosis, Leptospira, Primates.

RESUMO.- [Indícios de exposição a leptospiras em primatas neotropicais resgatados do comércio ilegal e de um Zoológico da Bahia.] Poucos estudos compararam a soroprevalência de aglutininas antileptospira com a demonstração de excreção urinária de leptospiras ou evidência de infecção ativa em primatas não humanos. A população

\footnotetext{
${ }^{1}$ Received on September 29, 2015.

Accepted for publication on May 31, 2016.

${ }^{2}$ Escola de Medicina Veterinária e Zootecnia, Universidade Federal da Bahia (UFBA), Av. Adhemar de Barros 500, Ondina, Salvador, BA 40170110, Brazil.E-mails: dalmeidastar@ig.com.br, arianneoria@ufba.br, melissahp@ig.com.br

${ }^{3}$ Centro de Pesquisa Gonçalo Moniz, Fundação Oswaldo Cruz, Rua Waldemar Falcão 121, Candeal, Salvador, BA 40296-710, Brazil. E-mails: caroline_luane@hotmail.com, deyasantos@hotmail.com,daa@ufba.br

${ }^{4}$ Escola Baiana de Medicina e Saúde Pública, Av. Dom João VI 274, Brotas, Salvador, BA 40285-001, Brazil. E-mail: caroline_luane@hotmail.com

${ }^{5}$ Parque Zoobotânico Getúlio Vargas, Alto de Ondina s/n, Ondina, Salvador, BA 40170-110, Brazil. E-mail: vinicius.dantas@inema.ba.gov.br

${ }^{6}$ Centro de Triagem de Animais Silvestres Chico Mendes (CETAS), Rua Fernando Pedreira s/n, Estrada das Barreiras, Cabula, Salvador, BA 41195220, Brazil.E-mail: fvetibama@yahoo.com.br

${ }^{7}$ Departamento de Patologia e Medicina Legal, Faculdade de Medicina, UFBA, Praça XV de Novembro s/n, Largo do Terreiro de Jesus, Salvador, BA 40025-010, Brazil. *Corresponding author: daa@ufba.br
}

estudada consistiu em 58 animais, sendo 42 primatas do Parque Zoobotânico Getúlio Vargas, Bahia, Brasil. 0 estudo avaliou ainda 16 primatas (Cebus sp.) resgatados do tráfico ilegal e abrigados no Centro de Triagem de Animais Silvestres Chico Mendes, Salvador, Bahia, Brasil. A soroprevalência de anticorpos antileptospira foi baixa $(2 \%)$ nos animais do Zoológico. Uma taxa mais elevada (31\%) foi observada nos animais resgatados do tráfico ilegal. Mesmo que todas as amostras de sangue e urina tenham sido negativas para DNA de leptospiras, a alta frequência de evidência de exposição nos animais de origem selvagem indicam o risco potencial da adoção de primatas como animais de estimação.

TERMOS DE INDEXAÇÃO: Leptospirose, Leptospira, Primatas.

\section{INTRODUCTION}

Leptospirosis is a widespread zoonosis caused by pathogenic leptospires. Humans acquire infection by direct exposure to contaminated urine from mammalian reservoirs or, more commonly, by exposure to contaminated soil or water. The disease occurs in different settings associated with a wide range of reservoirs, such as field mice in paddy fiel$\mathrm{ds}$, farm animals in occupational exposures, urban rodents 
in large urban areas with poor sanitation, and wild animals in water sports and ecotourism related exposures (Bharti et al. 2003). Most human infections are asymptomatic or cause mild febrile illness that is indistinguishable from diseases caused by other infectious agents. However, 5-10\% of human infections will become severe, resulting in the Weil's triad of acute renal failure, hemorrhages, and jaundice (with 5-30\% fatality) or severe pulmonary hemorrhagic syndrome (SPHS, with $\geq 50 \%$ fatality) (WHO 2003a, McBride et al. 2005, Medeiros et al. 2010).

Non-human primates usually develop a self resolving, mild illness in naturally acquired or experimental infections ( Minette 1966, Minette \& Shaffer 1968, Hambleton et al. 1980, Marshall et al. 1980), but some species may deve- lop severe disease. Experimental infection mirrored lethal human cases with pulmonary hemorrhages, liver necrosis, and tubular nephritis in marmoset monkeys (Callithrix jacchus), and an outbreak of pulmonary hemorrhage spreaded among naturally infected capuchin monkeys in a wildlife rehabilitation center in Colombia (Pereira et al. 2005). There is a significant public health concern associated with illegal wildlife ownership, as wild animals are estimated to be the source of over $70 \%$ of all emerging infections (Chomel et al. 2007). Seroprevalence of antileptospiral antibodies in Neotropical primates from zoos in Latin America or from wildlife is variable, partly due to the diverse species studied and the different cutoffs employed (Table 1 and 2) (Baulu et al. 1987, Kessler \& Everard 1988, Perolat et al. 1992, Luna-

Table 1. Studies in Latin America on the serologic evidence of exposure to leptospires in non-human primates in captivity

\begin{tabular}{|c|c|c|c|c|}
\hline Author, year & Site, City, Country & Species & $\mathrm{N} / \mathrm{n}(\%)$ & Predominant serogroup \\
\hline Baulu et al. 1987 & $\begin{array}{c}\text { Research Center, } \\
\text { Saint Joseph, Barbados }\end{array}$ & Cercopithecus aethiops sabeaus (Vervet Monkey) & $6 / 24(25)$ & Ballum \\
\hline Perolat et al. 1992 & $\begin{array}{c}\text { Instituto Pasteur, Caiena, } \\
\text { Guiana Francesa }\end{array}$ & Saimiri sciureus (Common Squirrel Monkey) & $24 / 93(26)$ & Icterohaemorrhagiae \\
\hline \multirow[t]{5}{*}{ Luna-Alvarez et al. 1996} & \multirow{5}{*}{$\begin{array}{l}\text { Chapultepec Zoo, Cidade } \\
\text { do México, México }\end{array}$} & Pongo pygmaeus (Bornean Orangutan) & $2 / 3(66)$ & \multirow[t]{5}{*}{ Canicola } \\
\hline & & Ateles belzebuth (White-fronted Spider Monkey) & $2 / 2(100)$ & \\
\hline & & Ateles paniscus (Black Spider Monkey) & $3 / 6(50)$ & \\
\hline & & Macaca fuscata (Japanese Macaque) & $1 / 3(66)$ & \\
\hline & & Papio ursinus (Chacma Baboon) & $1 / 1(100)$ & \\
\hline $\begin{array}{l}\text { Ibanez-Contreras } \\
\text { et al. 2010* }\end{array}$ & $\begin{array}{l}\text { Research Center, Cidade } \\
\text { do México, México }\end{array}$ & Macaca mulatta (Rhesus Macaque) & $18 / 59(30)$ & $\begin{array}{c}\text { Panama, } \\
\text { Icterohaemorrhagiae, } \\
\text { Autralis, and Shermani }\end{array}$ \\
\hline \multirow[t]{4}{*}{ Lilenbaum et al. $2002^{* *}$} & \multirow[t]{4}{*}{ Zoo, Rio de Janeiro, Brazil } & Ateles belzebuth (White-fronted Spider Monkey ) & $2 / 2(100)$ & \multirow{4}{*}{$\begin{array}{l}\text { Autralıs, and Shermanı } \\
\text { Icterohaemorrhagiae }\end{array}$} \\
\hline & & Ateles paniscus (Black Spider Monkey) & $3 / 6(50)$ & \\
\hline & & Macaca fuscata (Japanese Macaque) & $1 / 3(66)$ & \\
\hline & & Papio ursinus (Chacma Baboon) & $1 / 1(100)$ & \\
\hline \multirow[t]{14}{*}{ Corrêa et al. 2004} & \multirow[t]{14}{*}{ Zoo, São Paulo, Brazil } & Callithrix jacchus (Common Marmoset) & \multirow{14}{*}{$\begin{array}{c}24 / 99 \\
(24)\end{array}$} & \multirow[t]{14}{*}{ Castellonis } \\
\hline & & & & \\
\hline & & Callithrix penicillata (Black-tufted Marmoset) & & \\
\hline & & & & \\
\hline & & Saguinus fuscicolis (Brown-mantled Tamarin) & & \\
\hline & & Saimiri sciureus (Common Squirrel Monkey) & & \\
\hline & & Cebus apella (Tufted Capuchin) & & \\
\hline & & & & \\
\hline & & Ateles paniscus (Black Spider Monkey) & & \\
\hline & & & & \\
\hline & & Lagothrix lagothricha (Brown Woolly Monkey) & & \\
\hline & & Cebus nigrivitatus (Capuchin Monkeys) & & \\
\hline & & Aotus trvirgatus (Three-striped Night Monkey) & & \\
\hline & & Alouatta fusca (Brown Howler Monkey) & & \\
\hline \multirow[t]{2}{*}{ Lilenbaum et al. 2005} & Primatology center, & Leontopithecus sp. (Lion Tamarin) & \multirow[t]{2}{*}{$26 / 73(36)$} & Icterohaemorrhagiae \\
\hline & Rio de Janeiro, Brazil & & & \\
\hline \multirow[t]{2}{*}{ Pimentel et al. 2009} & \multirow[t]{2}{*}{ Zoo, Aracaju, Brazil } & Cebus libinosus (Black-striped Capuchin) & $1 / 14(7)$ & Icterohaemorrhagiae \\
\hline & & Cebus xanthosternus (Yellow-breasted capuchin) & $1 / 4(25)$ & Icterohaemorrhagiae \\
\hline \multirow[t]{2}{*}{ Szonyi et al. 2010} & Rehabilitation center, & Cebus sp. (Capuchin) & \multirow[t]{2}{*}{$37 / 52(71)$} & Icterohaemorrhagiae \\
\hline & \multicolumn{2}{|l|}{ Valle de Aburrá, Colombia } & & \\
\hline \multirow[t]{6}{*}{ Romero et al. 2011} & Mantecaña Zoo, Cidade & Ateles fusiceps (Black-headed Spider Monkey) & $5 / 19(33)$ & Icterohamorhagiae \\
\hline & \multirow[t]{5}{*}{ Pereira, Colombia } & Cebus apella (Tufted Capuchin) & $1 / 14(7)$ & \\
\hline & & Cebus capucinus (White Faced Capuchin) & $1 / 3(33)$ & \\
\hline & & Cebus albifrons (White-fronted capuchin) & $5 / 6(83)$ & \\
\hline & & Ateles hybridus (Brown Spider Monkey) & $1 / 6(17)$ & \\
\hline & & Saguinus leoucopus (White-footed Tamarin) & $2 / 5(40)$ & \\
\hline Ferreira et al. 2011 & CETAS, Northeast Brazil & Cebus sp. (Capuchin) & $9 / 139(6,5)$ & Semaranga \\
\hline Pinna et al. 2012 & CETAS, Salvador, Brazil & Callithrix jacchus (Common Marmoset) & $16 / 28(57)$ & Icterohaemorrhagiae \\
\hline & & Callithrix penicillata (Black-tufted Marmoset) & $4 / 8(50)$ & \\
\hline & & Cebus sp. (Capuchin) & $8 / 5(62,5)$ & \\
\hline Ullman et al. 2012 & Zoo, Sorocaba, Brazil & Alouatta caraya (Black howler) & $1 / 3(33)$ & Icterohaemorrhagiae \\
\hline & & Ateles marginatus (White-cheeked Spider Monkey) & $2 / 6(33)$ & \\
\hline & & Brachyteles arachnoides (Southern Woolly Spider Monkey) & $1 / 9(11)$ & \\
\hline
\end{tabular}

Note: All studies used the cutoff of 1:100 MAT titers except for * and **, which used 1:20 and 1:200 cutoffs, respectively. 
Table 2. Studies in Latin America on the serologic evidence of exposure to leptospires in non-human primates captured from the wild

\begin{tabular}{|c|c|c|c|c|}
\hline Author, year & Site, City, Country & Species & $\mathrm{N} / \mathrm{n}(\%)$ & Predominant serogroup \\
\hline \multirow[t]{2}{*}{ Souza Júnior et al. 2002} & Lajeado/ Ipueras, Brazil & Alouatta caraya (Black howler) & $46 / 82(16)$ & Pomona \\
\hline & & Cebus sp. (Capuchin) & $2 / 286(2)$ & Panama \\
\hline Baulu et al. 1987 & Research Center, Barbados, Caribe & Cercopithecus aethiops sabeaus (Vervet Monkey) & $150 / 501(30)$ & Ballum \\
\hline Kessler \& Everard 1988 & Caio Santiago, Porto Rico & Macaca mulatta (Rhesus Macaque) & $5 / 169(3)$ & Icterohaemorrhagiae \\
\hline
\end{tabular}

-Alvarez et al. 1996, Lilenbaum et al. 2002, Correa et al. 2004, Lilenbaum et al. 2005, Souza Júnior et al. 2006, Pimentel et al. 2009, Ibáñez-Contreras et al. 2010, Ferreira et al. 2011, Romero et al. 2011, Szonyi et al. 2011, Pinna et al. 2012, Ullmann et al. 2012). Few studies have compared the serological evidence of leptospirosis exposure with the molecular evidence of active infection (detection of DNA fragments in blood samples) or the renal carrier state (detection of DNA in urine) in non-human primates (Ullmann et al. 2012). The aim of this study was to investigate the serological evidence of exposure and the presence of DNA fragments of pathogenic leptospires in the blood and urine samples of Neotropical primates from two sources, a zoological park and a wild life rehabilitation center in Salvador, Bahia, Brazil.

\section{MATERIALS AND METHODS}

In the present study, 58 of non-human primates were evaluated. The population included 42 monkeys from the Zoological Park of Salvador (Parque Zoobotânico Getúlio Vargas), Bahia, Brazil. These animals belonged to the following species: Cebus xanthosternos $(\mathrm{n}=23)$, Cebus flavius $(\mathrm{n}=11)$, Alouatta caraya $(\mathrm{n}=3)$, Aottus $\mathrm{sp}$. $(\mathrm{n}=4)$, and Saimiri sciureus $(\mathrm{n}=1)$. The study also evaluated 16 primates rescued from illegal trade that were housed in the wildlife rehabilitation center of Salvador (Centro de Triagem de Animais Silvestres Chico Mendes, CETAS), Bahia, Brazil. All these animals were identified as Cebus sp., as many of them are hybrids.

Microscopic agglutination tests (MAT) were performed, according to recommended protocols (Faine et al. 1999, WHO 2003), and included twenty-three WHO reference strains and a local isolate (serovar Copenhageni strain L1130) (Ko et al. 1999, Nascimento et al. 2004). Titers $\geq 1: 100$ were considered positive. Polymerase chain reaction for the detection of the lipL32 gene was performed as previously described (Rojas et al. 2010, Chagas-Junior et al. 2012).

The research protocols were approved by the Research Ethics Committee of the Faculdade Franca - SP (025/2009-A). In addition, they were in accordance with guidelines System Authorization and Information on Biodiversity the Ministry of Environment of Brazil (number 20831-1)

\section{RESULTS AND DISCUSSION}

In the present study, only one of 42 primates (2\%) from the Zoological Park of Salvador had positive serum samples, according to the MAT. This animal was an adult female Alouatta caraya (black howler) that had a positive serum sample of 1:100 with mixed reactions for the Bratislava and Icterohaemorrhagiae serogroups. This animal was housed in a cage with two other adults of the same species. The positive animal and one negative black howler were born in the Zoological Park, while the other negative adult came from illegal trade (CETAS). Urine and blood samples were negative for all 42 monkeys evaluated at the Zoological Park.
Such low seroprevalence was not expected. Salvador is the third most populated city in Brazil, with an estimated 2.6 million inhabitants, and $60 \%$ of those inhabitants live in slum communities (Riley et al. 2007). It is a large urban center with poor sanitation, and incidence of severe leptospirosis cases peak during rainy seasons and in association with floods (Ko et al. 1999, Costa et al. 2001, Riley et al. 2007). Reports from the Zoological personnel indicated that there is a high population of rodents in the park, and rodents are frequently observed to be in contact with the animals in their cages. In some surveys from Latin American zoos, the seroprevalence of antileptospiral antigens is highly variable among different species (Table 1), and higher rates were attributed to the contact of primates with urban rodents. Additionally, there is a high prevalence of Icterohaemorrhagiae as the predicted infecting serogroup in some of these studies (as implied by MAT highest titers), and this suggests that rodents are the source of non-primate infection because these serovars are known to be selectively carried by urban rodents such as the Brown (Rattus norvegicus) and Black rats (R. rattus) (Bharti et al. 2003). In a survey of captured rats in Salvador, $80 \%$ of a total 142 animals had positive cultures for leptospires from kidney or urine samples, and all 59 serotypes isolated by monoclonal antibodies were characterized as serovar Copenhageni (serogroup Icterohaemorrhagiae) (de Faria et al. 2008), which is the main cause of severe leptospirosis in Salvador and in other large urban Brazilian centers (Ko et al. 1999, Pereira et al. 2000). It is not possible to infer that the single Black Howler with a positive MAT acquired the infection from exposure to rats because it had a mixed reaction with the Bratislava serogroup, which has no known selectivity for rodents.

In summary, the results from the Zoological Park suggest that the Neotropical primates' contact with rodents was not associated with an increased seroprevalence of antileptospiral antibodies. These species may be intrinsically more resistant than others in terms of acquiring leptospiral infection, or conversely, these animals may have had previous exposure in the wild that is associated with a progressive decrease in antileptospiral antibodies during the period of captivity.

In 2009, a previous survey performed in the wildlife rehabilitation center of Salvador (CETAS) found 57\% (25/44) seropositivity by MAT. In that study, marmosets were mainly affected, and positive samples were distributed as follows: Callithrix jacchus (common marmoset, 16/28: 57\%), Callithrix pennicilata (Black-tufted marmoset, 4/8: 50\%), and Cebus sp. (capuchin monkeys, 5/8: 63\%) (Pinna et al. 2012). In this study were found $5 / 16$ (31\%) positive serum samples by MAT from Cebus sp. 
Thus, the high rate of serological evidence of Leptospira exposure seems to be a consistent finding among animals from the wild that are rescued from illegal trade in the state of Bahia. It is important to note, however, that the predicted infecting serogroup inferred by MAT highest titers was Icterohaemorrhagiae in $84 \%$ of the cases in a former study. In this study, the five positive samples were distributed in the following predicted serogroups: Ballum (1:100), Semaranga (1:200), Grippotyphosa (1:100), Cynopeteri (1:100), and a mixed reaction of Tarassovi/Autumnalis (1:100). Thus, while the high frequency of Icterohaemorrhagiae indicated that monkeys could have acquired infection after they were caught in the wild, the wide range of predicted serogroups in the present study indicates that these animals may have been exposed to many potential sources of infection in the wild. In addition to conservation concerns, these data point toward the potential risk of keeping these animals as pets as it appears that they may be exposed to leptospiral infection in the wild or after entrapment.

This study also evaluated the possible association of serological evidence of exposure with active infection and renal carriage using PCR detection of leptospiral DNA in blood and urine samples, respectively. None of the evaluated samples yielded positive results. Further studies with larger sample groups of animals rescued from illegal trade are warranted to estimate the risks of infection from intimate contact with exotic animals, including Neotropical primates, when kept as pets.

\section{CONCLUSIONS}

The seroprevalence of antileptospiral antibodies was low (2\%) in the Zoological Park of Salvador, Brazil, despite the high frequency of rodents in the area and the endemicity of human leptospirosis in Salvador.

A higher rate $(31 \%)$ was observed among the animals rescued from illegal trade in the state of Bahia.

Serological evidence of exposure does not predict an active infection or the renal carrier state in non-human primates.

Even if all the blood and urine samples were negative for leptospiral DNA fragments, the high frequency of serological evidence of exposure suggests a potential risk of leptospirosis transmission when keeping these animals as pets.

Acknowledgements.- The authors are grateful to Victor Pereira Curvelo for technical assistance on animal capture and contention during the survey performed in the Zoological Park of Salvador, Brazil.

\section{REFERENCES}

Baulu J., Everard C.O. \& Everard J.D. 1987. Leptospires in vervet monkeys (Cercopithecus aethiops sabaeus) on Barbados. J. Wildl. Dis. 23:60-66.

Bharti A.R., Nally J.E., Ricaldi J.N., Matthias M.A., Diaz M.M., Lovett M.A., Levett P.N., Gilman R.H., Willig M.R., Gotuzzo E. \& Vinetz J.M. 2003. Leptospirosis: a zoonotic disease of global importance. Lancet Infect. Dis. 3:757-771.

Chagas-Junior A.D., Silva C.L., Soares L.M., Santos C.S., Silva C.D., Athanazio D.A., Reis M.G., McBride F.W. \& McBride A.J. 2012. Detection and quantification of Leptospira interrogans in hamster and rat kidney samples: immunofluorescent imprints versus real-time PCR. PloS one 7:e32712.
Chomel B.B., Belotto A. \& Meslin F.X. 2007. Wildlife, exotic pets, and emerging zoonoses. Emerg. Infect. Dis. 13:6-11.

Correa S.H.R., Vasconcellos S.A., Morais Z., Teixeira A.A., Dias R.A., Guimarães M.A.B.V., Ferreira F. \& Neto J.S.F. 2004. Epidemiologia da Leptospirose em animais silvestres na Fundação Parque Zoológico de São Paulo. Braz. J. Vet. Res. Anim. Sci. 41:189-193.

Costa E., Costa Y.A., Lopes A.A., Sacramento E. \& Bina J.C. 2001. Formas graves de leptospirose: aspectos clínicos, demográficos e ambientais. Revta Soc. Bras. Med. Trop. 34:261-267.

de Faria M.T., Calderwood M.S., Athanazio D.A., McBride A.J., Hartskeerl R.A., Pereira M.M., Ko A.I. \& Reis M.G. 2008. Carriage of Leptospira interrogans among domestic rats from an urban setting highly endemic for leptospirosis in Brazil. Acta Tropica 108:1-5.

Faine S.B., Adler B., Bolin C. \& Perolat P. 1999. Leptospira and Leptospirosis. 2nd ed. MediSci, Melbourne.

Ferreira D.R.A., Laroque P.O., Wagner P.G.C., Higino S.S.S., Azevedo S.S., Rego E.W. \& Mota R.A. 2011. Ocorrência de anticorpos e fatores de risco associados à infecção por Leptospira spp. em Cebus spp. mantidos em cativeiro no Nordeste do Brasil. Pesq. Vet. Bras. 31:1019-1023.

Hambleton P., Baskerville A., Marshall R.B., Harris-Smith P.W. \& Adams G.D. 1980. Metabolic sequelae of experimental leptospirosis in grivet monkeys. Brit. J. Exp. Pathol. 61:16-21.

Ibáñez-Contreras A., Hernández-Godínez B., Torres- Barranca J.I. \& Meléndez-Vélez P. 2010. Hallazgos de anticuerpos contra Leptospira sp., serovariedades Panama, Lai, Australis, Shermani y Patoc, en un grupo de monos rhesus (Macaca mulatta) en condiciones de cautiverio. Archivos de Medicina Veterinaria 42:101-104.

Kessler M.J. \& Everard C.O.R. 1988. Leptospiral agglutinins in the Cayo Santiago macaques. Am. J. Primatol. 14:369-373.

Ko A.I., Galvao Reis M., Ribeiro Dourado C.M., Johnson Jr W.D. \& Riley L.W. 1999. Urban epidemic of severe leptospirosis in Brazil. Salvador Leptospirosis Study Group. Lancet 354:820-825.

Lilenbaum W., Monteiro R.V., Ristow P., Fraguas S., Cardoso V.S. \& Fedullo L.P. 2002. Leptospirosis antibodies in mammals from Rio de Janeiro Zoo, Brazil. Res. Vet. Sci. 73:319-321.

Lilenbaum W., Varges R., Moraes I.A., Ferreira A.M. \& Pissinatti A. 2005. Leptospiral antibodies in captive lion tamarins (Leontopithecus sp) in Brazil. Vet. J. 169: 462-464.

Luna-Alvarez M.A., Moles-Cervantes L.P., Torres-Barranca J.I. \& Gual-Sill F. 1996. Serological survey of leptospirosis in captive wildlife at the Chapultepec Zoo in Mexico City. Veterinaria, Mexico, 27:229-234.

Marshall R.B., Baskerville A., Hambleton P. \& Adams G.D. 1980. Benign leptospirosis: the pathology of experimental infection of monkeys with Leptospira interrogans serovars balcanica and tarassovi. Brit. J. Exp. Pathol. 61:124-131.

McBride A.J., Athanazio D.A., Reis M.G. \& Ko A.I. 2005. Leptospirosis. Curr. Opin. Infect. Dis. 18: 376-386.

Medeiros F.R., Spichler A. \& Athanazio D.A. 2010. Leptospirosis-associated disturbances of blood vessels, lungs and hemostasis. Acta Trop. 115:155-162.

Minette H.P. 1966. Leptospirosis in primates other than man. Am. J. Trop. Med. Hyg. 15:190-198.

Minette H.P. \& Shaffer M.F. 1968. Experimental leptospirosis in monkeys. Am. J. Trop. Med. Hyg. 17:202-212.

Nascimento A.L., Ko A.I., Martins E.A., Monteiro-Vitorello C.B., Ho, P.L., Haake D.A., Verjovski-Almeida S., Hartskeerl R.A., Marques M.V., Oliveira M.C., Menck C.F., Leite L.C., Carrer H., Coutinho L.L., Degrave W.M., Dellagostin O.A., El-Dorry H., Ferro E.S., Ferro M.I., Furlan L.R., Gamberini M., Giglioti E.A., Goes-Neto A., Goldman G.H., Goldman M.H., Harakava R., Jeronimo S.M., Junqueira-de-Azevedo I.L., Kimura E.T., Kuramae E.E., Lemos E.G., Lemos M.V., Marino C.L., Nunes L.R., Oliveira de R.C., Pereira G.G., Reis M.S., Schriefer A., Siqueira W.J., Sommer P., Tsai S.M., Simpson A.J., Ferro J.A., Camargo L.E., Kitajima J.P., Setubal J.C. \& Van S.M.A. 2004. Comparative genomics of two Leptospira interrogans serovars reveals novel insights into physiology and pathogenesis. J. Bacteriol. 186:2164-2172.

Pereira M.M., Da Silva J.J., Pinto M.A., Da Silva M.F., Machado M.P., Lenzi 
H.L. \& Marchevsky R.S. 2005. Experimental leptospirosis in marmoset monkeys (Callithrix jacchus): a new model for studies of severe pulmonary leptospirosis. Am. J. Trop. Med. Hyg. 72:13-20.

Pereira M.M., Matsuo M.G.S., Bauab A.R., Vasconcelos S.A., Moraes Z.M., Baranton G. \& Saint G.I. 2000. A clonal subpopulation of Leptospira interrogans sensu stricto is the major cause of leptospirosis outbreaks in Brazil. J. Clin. Microbiol. 38:450-452.

Perolat P., Poingt J.P., Vie J.C., Jouaneau C., Baranton G. \& Gysin J. 1992. Occurrence of severe leptospirosis in a breeding colony of squirrel monkeys. Am. J. Trop. Med. Hyg. 46:538-545.

Pimentel J.S., Gennari S.M., Dubey J.P., Marvulo M.F.V., Vasconcellos S.A., Morais Z.M., Silva J.C.R. \& Evêncio Neto J. 2009. Inquérito sorológico para toxoplasmose e leptospirose em mamíferos selvagens neotropicais do Zoológico de Aracaju, Sergipe. Pesq. Vet. Bras. 29:1009-1014.

Pinna M.H., Martins G., Pinheiro A.C., Almeida D.S., Oria A.P. \& Lilenbaum W. 2012. Detection of anti-Leptospira antibodies in captive nonhuman primates from Salvador, Brazil. Am. J. Primatol. 74:8-11.

Riley L.W., Ko A.I., Unger A. \& Reis M.G. 2007. Slum health: diseases of neglected populations. BMC Int. Health Hum. Rights 7:2.
Rojas P., Monahan A.M., Schuller S., Miller I.S., Markey B.K. \& Nally J.E. 2010. Detection and quantification of leptospires in urine of dogs: a maintenance host for the zoonotic disease leptospirosis. Eur. J. Clin. Microbiol. Infect. Dis. 29:1305-1309.

Romero M.H., Astudillo M., Sanchez J.A., Gonzalez L.M. \& Varela N. 2011. Anticuerpos contra Leptospira sp. en primates neotropicales y trabajadores de un zoológico colombiano. Revta Salud Publica 13:814-823.

Souza Júnior M.F., Lobato Z.I.P., Lobato F.C.F., Moreira E.C., Oiveira R.R., Leite G.G., Freitas T.D. \& Assis R.A. 2006. Presença de anticorpos da classe IgM de Leptospira interrogans em animais silvestres do Estado do Tocantins, 2002. Revta Soc. Bra. Med. Trop. 39:292-294.

Szonyi B., Agudelo-Florez P., Ramirez M., Moreno N. \& Ko A.I. 2011. An outbreak of severe leptospirosis in capuchin (Cebus) monkeys. Vet. J. 188:237-239.

Ullmann L.S., Neto R.N.D., Teixeira R.H.F., Nunes A.V., Silva R.C., Pereira-Richini V.B. \& Langoni H. 2012. Epidemiology of leptospirosis at Sorocaba Zoo, São Paulo state, Southeastern Brazil. Pesq. Vet. Bras. 32:1174-1178.

WHO 2003. Human Leptospirosis: guidance for diagnosis, surveillance and control. Malta. 